\title{
Meiofaunal vertical zonation on hard-bottoms: comparison with soft-bottom meiofauna
}

\author{
Roberto Danovaro $^{1,2, *}$, Simonetta Fraschetti ${ }^{3}$ \\ ${ }^{1}$ Institute of Marine Science, Faculty of Science, University of Ancona, Via Brecce Bianche, \\ 60131 Ancona, Italy \\ ${ }^{2}$ DISTeBA, Department of Zoology and Marine Biology, University of Bari, Via Orabona 4, 70125 Bari, Italy \\ ${ }^{3}$ Laboratory of Zoology and Marine Biology, University of Lecce, 73100 Lecce, Italy
}

\begin{abstract}
An annual study on hard-substrate meiofaunal assemblages was carried out at 2 depths ( 2.5 and $8 \mathrm{~m}$ ) along a vertical cliff of the Middle Adriatic (Mediterranean Sea) characterised by different macroalgal canopies and structural substrate complexities. The upper sampling area of the rocky cliff was covered by macroalgae, and its upper limit was characterised by the presence of a dense belt of Mytilus galloprovincialis. At $8 \mathrm{~m}$ depth, mussels were not present, the algal assemblage was less diversified, and phytal coverage decreased. Dynamics and community structure of meiofauna-inhabiting hard substrates were compared with those of meiofauna collected from soft sediments at the cliff base (9 m depth). Meiofauna of hard and soft substrates displayed significant differences both in terms of density (7-fold higher in soft substrates) and assemblage structure. Meiofauna from rocky substrates were dominated by crustaceans (copepods, nauplii and amphipods), while soft sediments were largely dominated by nematodes (ca 90\%). Significant temporal changes of meiofaunal density were observed on both hard and soft substrates, with higher densities in spring to summer and lowest abundance in winter. Despite a completely different algal assemblage and coverage at 2.5 and $8 \mathrm{~m}$ depths, hard substrates displayed very similar meiofaunal densities and community structure. Crustacean taxa were correlated with algal coverage. Polychaetes inhabiting hard substrates increased their relevance with depth, whilst amphipods, being significantly correlated with algal biomass, decreased. Nematodes were related with the structural complexity index, calculated on the basis of macroalgal geometric complexity and biomass, whereas copepod and nauplius densities were related with the total structural complexity (as a sum of the algal complexity). The results of the present study indicate that the nature of the substrate (hard vs soft) is the main factor responsible for the differences observed between hard- and soft-bottom meiofauna assemblages, whereas phytal coverage and substrate complexity influenced the structure of hard bottom meiofaunal assemblages. Finally, the analysis of spatial variability of meiofaunal assemblages indicates that hydrodynamic stress also played an important role in meiofaunal structure and distribution on hard substrates, especially at shallow depths.
\end{abstract}

KEY WORDS: Meiofauna $\cdot$ Hard substrates $\cdot$ Soft substrates $\cdot$ Algal coverage $\cdot$ Substrate complexity Mediterranean Sea

Resale or republication not permitted without written consent of the publisher

\section{INTRODUCTION}

Historically, rocky-subtidal communities are among the least studied of all marine biota, especially with respect to ecological aspects (Fraschetti et al. 2001). This particularly applies to meiofauna that, in the last

*E-mail: danovaro@unian.it
$20 \mathrm{yr}$, has been almost exclusively investigated on soft bottoms (Higgins \& Thiel 1988, Danovaro et al. 2000).

Rocky subtidal communities generally show a wide range of species with highly different life cycles and recruitment strategies from those displayed by softbottom assemblages from the same areas at similar depths (Sutherland \& Ortega 1986, Crowe et al. 1987, Albertelli et al. 1999). This is not confirmed in the 
meiofaunal compartment. The very concept of meiofauna, indeed, derives from studies on sub-littoral soft bottoms and is almost synonymous with interstitial fauna (e.g. Higgins \& Thiel 1988, Boucher \& Gorbault 1990, Aller \& Aller 1992, Danovaro et al. 1995, Fleeger et al. 1995, Ólaffson 1995, Vanhove et al. 1998, Coull 1999, Steyaert et al. 1999).

Soft-bottom meiofauna are characterised by very high biodiversity, some phyla being exclusive of this size class (e.g. Loricifera, Gnatostomulida, Tardigrada, Gastrotricha, Kinorhyncha; Higgins \& Thiel 1988, Clarke \& Warwick 1999). This is not the case for hard substrates where meiofauna, owing to their small size, are usually neglected (Coull et al. 1983, Gibbons 1988a,b). In addition, the lack of sampling standardisation makes difficult adequate sampling and sorting for quantitative studies (Gibbons \& Griffiths 1988).

Two groups cumulatively dominate both soft- and hard-substrate (including phytal) meiofauna: nematodes and crustaceans (particularly harpacticoid copepods). The comparative analysis of soft and hard substrates can provide information on factors structuring meiofaunal assemblages: soft bottoms are generally largely dominated by nematodes, whereas hard bottoms are generally dominated by harpacticoid copepods, isopods and amphipods (Beckley 1982, Coull et al. 1983). Crustacean dominance on hard substrates becomes even more evident when considering biomass values (Beckley \& McLachlan 1980).

Meiofauna are dependent upon the characteristics of the substrate. On rocky substrates, macroalgae generally become a key component, as they: (1) represent an important trophic source for meiofaunal grazers and epi-growth feeders (Hicks 1980); (2) smooth turbulence, thus reducing meiofauna resuspension (Gibbons 1988a,b); (3) modify structural characteristics of the substrate and increasing sediment accumulation (Airoldi 1998); (4) increase substrate complexity, thus offering refuges from predation (Coull \& Wells 1982); and (5) increase habitat diversity, enhancing substrate colonisation (Gibbons 1988a,b, Gee \& Warwick 1994). Finally, macroalgae represent an optimal substrate for the recruitment of several benthic species (including polychaetes, bivalves and amphipods; Beckley 1982, Coull et al. 1983).

Hard substrates are also generally characterised by a high substrate complexity, largely accounted for by phytal components and sessile organisms. Algal biomass and volume have been widely utilised as an index to estimate their complexity (Coull et al. 1983, Stoner \& Lewis 1985, Hall \& Bell 1988), but their inadequacy has been stressed by several authors (Russo 1990, Gee \& Warwick 1994). In contrast, structural complexity of soft bottoms is generally accounted for by measures of sediment texture.
Finally, hard-substrate characteristics are deeply influenced by the life cycles of epibiontic organisms, so that seasonal studies are required when we compare hard- and soft-bottom substrate assemblages.

In this study we investigated hard-substrate meiofaunal assemblages at 2 depths along a cliff with different macroalgal canopies and structural complexities. This study is, to our knowledge, the first attempt to compare hard-substrate meiofaunal dynamics with the meiofauna-inhabiting sediments at the cliff base. We considered meiofauna associated to macroalgae and to the rock surface beneath the algae and hypothesise that hard- and soft-substrate meiofaunal composition, abundance and temporal changes are different, being dependent upon different constraints.

\section{MATERIALS AND METHODS}

Study area and sampling sites. The northern Adriatic is characterised by large nutrient inputs coming from the Po River, which extends its plume down to the Conero promontory (Artegiani \& Azzolini 1981). This is the only rocky shore area of the western Adriatic coast along about $800 \mathrm{~km}$ of coastline (from the Po River delta to the Gargano in Apulia), thus representing a key source area for the recruitment of several benthic, and bentho-nekton species. Main currents (always $<10 \mathrm{~cm} \mathrm{~s}^{-1}$ ) flow in a south to eastward direction and are affected by the promontory presence deviating water flow towards the open sea. Several vertical cliffs extending to about $10-15 \mathrm{~m}$ depth were investigated during a preliminary survey along about $3 \mathrm{~km}$ of coastline. Among those analysed, the Trave site displayed the highest meiofaunal richness and percentage algal cover (R. Danovaro unpubl. data; Fig. 1). The trave site is a vertical carbonate cliff, perpendicular to the coastline and extending for $400 \mathrm{~m}$ before becoming submerged. Tidal excursion in the Mediterranean is negligible, and in the investigated area is $<30 \mathrm{~cm}$. Benthic sampling was carried out at 3 depths: Stn A (at $2.5 \mathrm{~m}$ depth), located in an area extensively colonised by macroalgae, is exposed to the wave action and characterised by a dense belt of mussels Mytilus galloprovincialis extending from the top of the cliff ( $0.5 \mathrm{~m}$ depth) to its upper limit; Stn B (at $8 \mathrm{~m}$ depth) is characterised by reduced algal cover and by the dominance of sponges; and Stn C (at $9 \mathrm{~m}$ depth) is located at the cliff base and is characterised by sandy-muddy sediments.

Environmental variables. Sampling was carried out from May 1997 to May 1998, on a monthly basis (except in July, October, December 1997 and April 1998 when sampling was not performed due to adverse meteorological conditions; on February 1998 sampling was only performed at Stn A). At each 
sampling date, sea conditions (Beaufort scale), surface temperature (accuracy $0.1^{\circ} \mathrm{C}$ ) and transparency were recorded. Transparency was determined in situ at each sampling depth using a Secchi Disk (SD, white colour, $20 \mathrm{~cm}$ diameter) up to the distance of disk disappearance (measured horizontally in metres).

Meiofauna sampling and analysis. For hard-bottom meiofauna, based on the experience of Beckley \& McLachlan (1979), sampling was carried out by SCUBA divers by means of a modified manual corer. We evaluated sampling efficiency (expressed in terms of highest number of organisms and taxa) comparing 2 different corers designed for disruptive sampling. Additional analyses were carried out to identify the minimal sampling area using corers of diameters ranging from 3.7 to $20 \mathrm{~cm}$. To do this, 2 to 10 replicate cores were

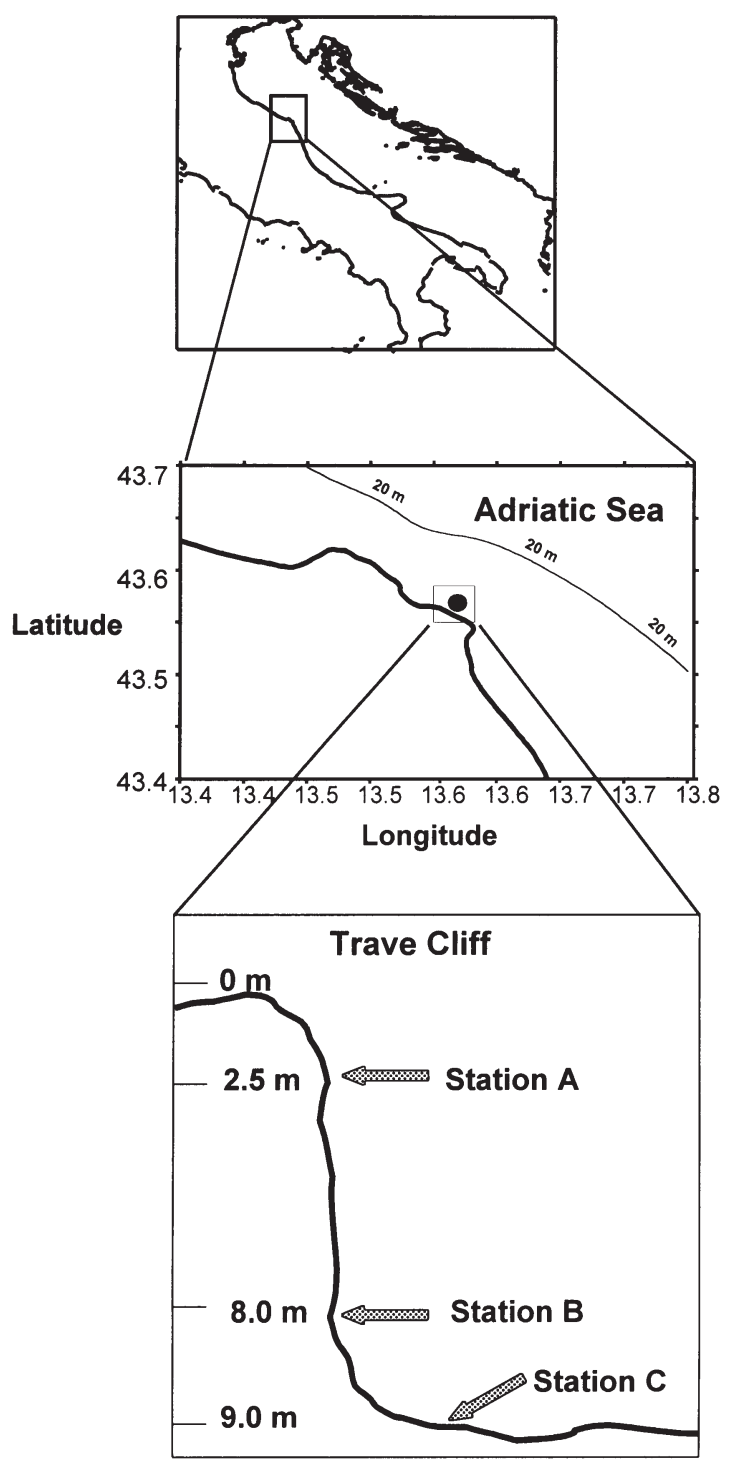

Fig. 1. Study area and sampling sites taken at both depths along the cliff before the start of the sampling period. On the basis of the obtained results, we selected a sampling corer composed of a cylinder (internal diameter, i.d., $8.5 \mathrm{~cm}, 14 \mathrm{~cm}$ length) open on the bottom (with a soft and $1 \mathrm{~cm}$ thick rubber O-ring to better adapt the opening to rough surfaces) and closed on top. The corer had a lateral window, $2 \mathrm{~cm}$ above the opening, hermetically closed by a lattice bag, enabling the SCUBA diver to scrape, using an internal spatula, the hard-bottom surface, removing also the algal cover (Fig. 2). This sampler enables the efficient removal of both macroalgae and the rock surface beneath the algae, thus avoiding the underestimation of meiofaunal densities, which is known to occur when only epiphytic algae are sampled (Gibbons \& Griffiths 1988).

Soft-bottom meiofauna was sampled, underneath the cliff, by penetrating transparent Plexiglas corers (i. d. $3.7 \mathrm{~cm}$ ) into the sediment down to a depth of $14 \mathrm{~cm}$. The use of 2 different-sized corers for hard and soft substrates allowed for collecting a similar number of organisms, thus optimising the conditions for comparison.

Additional samples $(\mathrm{n}=3,20 \times 20 \mathrm{~cm})$ were collected for macroalgal analysis in order to compare macroalgal assemblages together with meiofaunal samples and the actual algal community structure. At each depth and time, 3 replicate meiofaunal samples were taken. Each replicate was fixed with buffered formaldehyde (4\% final volume), stained with Bengal Rose and, to better detach organisms from macroalgae, samples were sonicated for $3 \mathrm{~min}$ (Branson Sonifier, $60 \mathrm{~W}$, 3 times for 1 min with $30 \mathrm{~s}$ intervals). Meiofauna was sieved through a $1 \mathrm{~mm}$ mesh net to retain macrobenthos, and macroalgae were fixed with $4 \%$ formaldehyde and stored in the dark until analysis. The sample fraction retained by a $37 \mu \mathrm{m}$ mesh net was added to Ludox HS 40 (density arranged to 1.15) for density centrifugation extraction (10 min, $800 \times g$, 3 times).

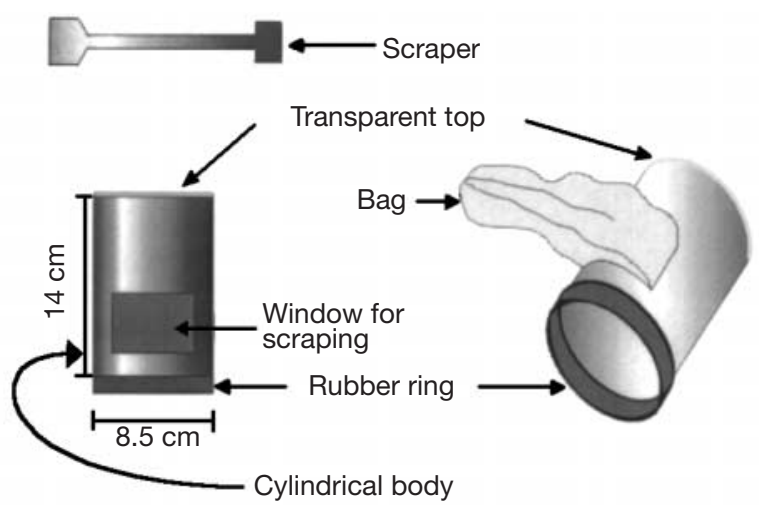

Fig. 2. Schematic structure of the sampler utilised for hardbottom meiofauna collection 
Samples were then re-stained with Bengal Rose and fixed with buffered formaldehyde ( $4 \%$ final volume in $0.4 \mu \mathrm{m}$ prefiltered seawater solution) in Falcon tubes $(50 \mathrm{ml})$. The same extraction technique and method of preservation were used for soft- and hard-bottom samples. All metazoan animals were counted and classified per taxon under a microscope using a Delfuss cuvette. All soft-body organisms were studied at 1000×. Additional samples were observed prior to fixation to better identify soft-body taxa.

Phytobenthos analysis. After sampling, algae were fixed with $4 \%$ formaldehyde and algal species identified under a microscope at $50 \times$ to $400 \times$. Algal sections were obtained by the use of cryotome, to investigate structural characteristics. Macroalgal wet weight was obtained gravimetrically after carbonate removal by $10 \% \mathrm{HCl}$ treatment.

The percentage of algal canopy was estimated visually during SCUBA diving at 2.5 and at $8 \mathrm{~m}$ depth using a frame $(100 \times 100 \mathrm{~cm})$ further divided into 100 square sectors $(10 \times 10 \mathrm{~cm})$ to facilitate visual census. At each sampling time, 3 to 5 replicates were taken at each station.

An index of structural complexity of the algal coverage was assigned to each algal species defined here as the complexity index (CI). The CI was arbitrarily scaled from 1 to 5 on the basis of the presence of: nodes, ramifications, fronds, cellular organisation and algal surface, and was classed as follows: 1, Cyanophyta sp.; 2, Erythrotrichia carnea (Dill W.) J. Ag.; 3, Ulva rigida C. Ag.; 4, Gracilaria confervoides (L.) Grev.; and 5, Ceramium diaphanum (Lightf.) Roth. To assign an index of structural complexity, all algal species encountered were analysed at different magnifications (from $6 \times$ to $48 \times$ under a binocular microscope, and at $400 \times$ using a light microscope). Algae with similar structural complexity were assigned to the same CI coefficient (see Table 2). At each sampling and depth, total structural complexity (TSC) was calculated by summing up the CI of each algal species. As the CI from each algal species, even cumulatively, does not take into account the packing density and quantitative importance of algal coverage, we calculated also the structural complexity index (SCI) as the product of TSC and algal biomass.

Statistical analyses. At each station, analysis of similarities (1-way ANOSIM, Clarke 1993) was used to analyse possible changes in the community structure during the sampled period. Two-way crossed ANOSIM was used to compare the 3 stations, under the hypothesis that the assemblages differ with depth in time. Data were 4th-root transformed to arrange all taxa in the same range of abundance (Clarke \& Warwick 1994).

Differences among samples were represented by non-metric multidimensional scaling ordinations (nMDS) (Clarke \& Warwick 1994). SIMPER was used to identify all 'important' taxa contributing $>10 \%$ to overall similarity, within all 3 sampling stations (Clarke 1993). All analyses were carried out using the PRIMER 5 programme (Plymouth Marine Laboratory, UK).

\section{RESULTS}

\section{Environmental variables}

Data on temperature, transparency and sea conditions during the study period are reported in Table 1 . In the study, temperature ranged from $7{ }^{\circ} \mathrm{C}$ in January and February to $24^{\circ} \mathrm{C}$ in August. Transparency at Stn A $(2.5 \mathrm{~m}$ depth) ranged from $50 \mathrm{~cm}$ in February to $6 \mathrm{~m}$ in May and August 1997 and from $<20 \mathrm{~cm}$ in January and February to $4.5 \mathrm{~m}$ in September at Stn B. Transparency at Stn B was similar but reduced, on average, by about 40 to $50 \%$ with respect to Stn A. Sea condition ranged from 0 to 1 (Beaufort scale) in May 1997, August, September, November and December, to $>3$ in February and March.

\section{Algal assemblages}

A total of 31 algal species were identified (Table 2). Macroalgal assemblages were dominated by Rhodo-

Table 1. Environmental variables at the Trave site. Reported are: temperature, transparency at the 2 sampling depths, sea conditions (Beaufort scale), mussel coverage (\%, only at Stn A), and phytal canopy at the 2 sampling depths $(\%)$. nd $=$ not determined

\begin{tabular}{|c|c|c|c|c|c|c|c|c|c|c|c|}
\hline Variable & Stn & Unit & May & Jun & Aug & Sep & Nov & Jan & Feb & Mar & May \\
\hline Temperature & & ${ }^{\circ} \mathrm{C}$ & 20 & 22 & 24 & 22 & 9 & 8 & 7 & 8 & 16 \\
\hline Transparency & A & $\mathrm{m}$ & 6.0 & 3.0 & 6.0 & 4.5 & 3.0 & 0.5 & 0.5 & 1.5 & 3.0 \\
\hline Transparency & B & $\mathrm{m}$ & 3.0 & 1.5 & 3.0 & 4.5 & 1.0 & $<0.2$ & $<0.2$ & 0.5 & 2.0 \\
\hline Sea conditions & & Beaufort scale & $0-1$ & $1-2$ & $0-1$ & $0-1$ & $0-1$ & $0-1$ & $3-5$ & $3-5$ & $1-2$ \\
\hline Mussel coverage $^{\mathrm{b}}$ & A & $\%$ & 100 & 20 & $100^{\mathrm{a}}$ & 60 & 80 & 90 & nd & 90 & 90 \\
\hline Macroalgal canopy & A & $\%$ & nd & 80 & $100^{\mathrm{a}}$ & $<5$ & $<5$ & 10 & nd & $<5$ & 5 \\
\hline Macroalgal canopy & B & $\%$ & nd & 70 & $100^{\mathrm{a}}$ & 0 & 0 & 0 & nd & 0 & 40 \\
\hline
\end{tabular}


phyceae ( $82.7 \%$ of encountered algal species), Phaeophyceae and Chlorophyceae (accounted together for $6.7 \%$ ), whilst Cyanophyceae represented ca. $4.0 \%$ of the algal species. Differences in algal community structure were observed comparing the 2 rocky stations (Fig. 3): at Stn A (2.5 m depth) Rhodophyceae accounted for $60 \%$ (May and June 1997) to $100 \%$ (March and May 1998) of the algal species collected: Phaeophyceae accounted for 9 to $20 \%$; and Cyanophyceae were observed only in August, when they represented from 7 to $13 \%$ of the total algal canopy. At Stn B $(8 \mathrm{~m})$ macroalgal coverage was absent in November and March. Rhodophyceae accounted for $100 \%$ of the algal assemblage, except in August when Chlorophyceae, Cyanophyceae and Rhodophyceae accounted together

Table 2. Algal species encountered on hard substrates at the Trave site. Reported is the relative contribution of each species to the total annual coverage (expressed as percentage). For more details on the structural complexity index (SCI) see 'Materials and Methods'. Canopy is expressed as percentage calculated as an annual average

\begin{tabular}{|c|c|c|}
\hline Species & CI & $\begin{array}{c}\% \\
\text { Canopy }\end{array}$ \\
\hline \multicolumn{3}{|l|}{ Rhodophyceae } \\
\hline Erythrotrichia carnea (Dill W.) J. Ag. & 2 & 2.66 \\
\hline Acrochaetium corymbiferum (Thur.) Batters & 3 & 4.00 \\
\hline Acrosorium uncinatum (J. Ag.) & 3 & 2.66 \\
\hline Acrosorium venulosum (Zanardini) Kylin & 3 & $<1$ \\
\hline Aglaothamnion sp. & 3.5 & 2.66 \\
\hline Antithamnion plumula (Ellis) Turn & 3.5 & $<1$ \\
\hline Antithamnion tenuissimum (Hauck) Schif. & 3.5 & 8.00 \\
\hline Antithamnion cruciatum (C. Ag.) Näg. & 3.5 & $<1$ \\
\hline Ceramium diaphanum (Lightf.) Roth & 5 & $<1$ \\
\hline Ceramium codii (Richards) G. Mazoiyer & 5 & 19.23 \\
\hline Ceramium tenuissimum (Lingbye) J. Aghard & 5 & $<1$ \\
\hline Chondria tenuissimma (Good et Wood) Ag. & 4 & 1.33 \\
\hline Compsothamnion thuyoides (Sm.) Naeg. & 3.5 & 8.00 \\
\hline Gelidium pulchellum (Turn.) Kütz & 4 & 2.66 \\
\hline Gracilaria compressa (Ag.) Grev. & 4 & $<1$ \\
\hline Gracilaria confervoides (L.) Grev. & 4 & 5.33 \\
\hline Hypnea musciformis (Wulf.) Lamour & 4 & 2.66 \\
\hline Chylocladia kaliformis (G. \& W.) Hook & 3.5 & 2.66 \\
\hline Lophosiphonia sp. & 5 & 4.00 \\
\hline Melobesia farinosa Lam. & 3 & 2.66 \\
\hline Nitophyllum sp. & 3 & 1.33 \\
\hline Pleonosporium sp. & 3.5 & 2.66 \\
\hline Polysiphonia pulvinata J. Ag. & 5 & 2.66 \\
\hline Rhodymenia palmetta (Esp.) Grev. & 3.5 & 4.00 \\
\hline \multicolumn{3}{|l|}{ Cyanophyceae } \\
\hline Cyanophyta sp. & 1 & 4.00 \\
\hline \multicolumn{3}{|l|}{ Phaeophyceae } \\
\hline Dictyota dichotoma J. Ag. & 3.5 & 2.66 \\
\hline Dictyopteris polipodioides Lamouroux & 4 & 2.66 \\
\hline Ectocarpus sp. & 3 & 1.33 \\
\hline \multicolumn{3}{|l|}{ Chlorophyceae } \\
\hline Cladophora dalmatica Kütz. & 3 & 5.33 \\
\hline Ulva rigida C. Ag. & 3 & 1.33 \\
\hline
\end{tabular}

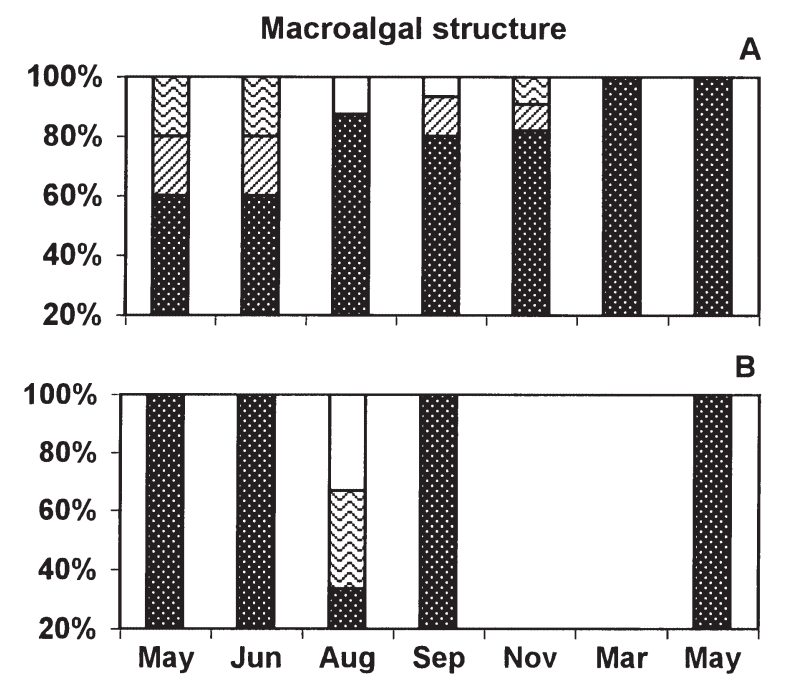

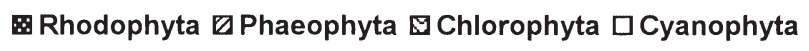

Fig. 3. Canopy of macroalgal assemblages (percentage contribution of the different taxa) at the 2 hard-bottom stations: (A) Stn A and (B) Stn B

for $1 / 3$ of the algal assemblage. The 3 dominant genera belonged to the Rhodophyceae: the first was Ceramium (accounting for about $20 \%$ of all algal specimens), followed by Compsothamnion (8\%) and Antithamnion $(<5 \%)$.

Algal canopy ranged from $80 \%$ at Stn A and $70 \%$ at Stn B in June, to ca. 0 in August, at both stations, when the cliff was completely covered by mucilage (Table 1). After this disturbance event macroalgae started recovering $(<5 \%$ at $2.5 \mathrm{~m}$, in September). Algal biomass ranged from 1.43 to $10.91 \mathrm{~g}$ per $10 \mathrm{~cm}^{2}$ (in August and May, respectively; this surface was used to compare algal parameters to meiofaunal data) at Stn A and from 0 (November and March) to $25.05 \mathrm{~g}$ per $10 \mathrm{~cm}^{2}$ in May at Stn B (Fig. 4).

The TSC was higher at Stn A (with values ranging from 8.5 to 51 ) than at Stn B (ranging from 8 to 22 ; Fig. 5A). The SCI displayed a completely different pat-

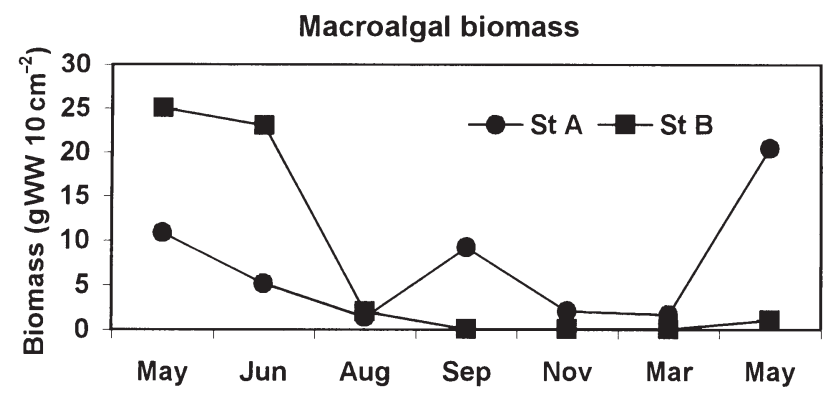

Fig. 4. Temporal changes of macroalgal biomass at the 2 hardbottom stations 

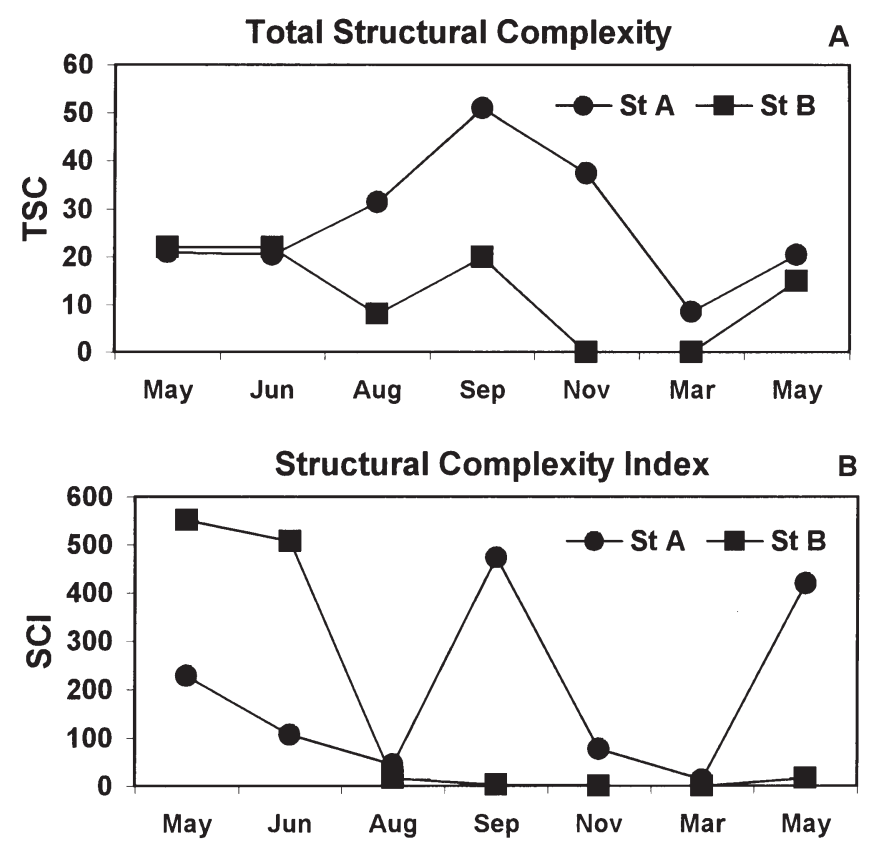

Fig. 5. Temporal changes of (a) total structural complexity and (b) structural complexity index at the 2 hard-bottom stations

tern from the TSC, reaching, at the 2 stations, highest values at different sampling times: at Stn B in May (551), while at Stn A in September (473; Fig. 5B).

\section{Meiofaunal assemblages}

Data relative to meiofaunal density and composition at Stns A, B (hard substrate) and C (soft substrate) are reported in Table 3. Meiofaunal density ranged from 165 to 795 ind. per $10 \mathrm{~cm}^{2}$, in March and August, respectively at Stn A and from 130 to 974 ind. per $10 \mathrm{~cm}^{2}$ in September and June at Stn B. Finally, meiofaunal density at the soft bottom Station (Stn C) ranged from 820 to 6298 ind. per $10 \mathrm{~cm}^{2}$, in November and March, respectively. Bivalves were considered separately (and included into 'Others') as they reached densities up to 2060 ind. per $10 \mathrm{~cm}^{2}$ at Stn A and 6358 ind. per $10 \mathrm{~cm}^{2}$ at Stn B, whereas bivalve density on sediments beneath the cliff was comparatively almost negligible ranging from 1 to 44 ind. per $10 \mathrm{~cm}^{2}$, in August and May, respectively.

Meiofaunal community structure is illustrated in Fig. 6. At Stn A, amphipods were the dominant taxon (mean $27 \%$ ), ranging from 1.3 to $72.1 \%$ of total meiofaunal density in August and March, respectively. Copepods accounted for 4.2 to $40.4 \%$ of total density (mean $23 \%$ ). Nauplii accounted for 5 to $41 \%$, (mean $19 \%)$. Nematodes accounted for 7 to $25 \%$, of total meiofaunal density (mean 18\%). Polychaetes ranged from 0.5 to $4.1 \%$ (mean $1.5 \%$ ). All other taxa (including ostracods, kinorhychs, turbellarians, oligochaetes, gastrotrichs, cnidarians, but excluding Mytilus galloprovincialis) ranged from 0.2 to $56 \%$ of total meiofauna (mean 12\%). At Stn B, harpacticoid copepods were dominant, accounting for 23 to $34 \%$ of total density (mean 29\%). Nauplii accounted for 8 to $32 \%$ (mean $19 \%$ ). Nematodes accounted for 15 to $38 \%$ of total meiofaunal density (mean 22\%). Amphipods (mean 14\%) ranged from 0.5 to $31.1 \%$ of total meiofaunal density. Polychaetes ranged from 3.5 to $11.3 \%$ (mean $7 \%$ ). All other taxa (M. galloprovincialis excluded) ranged from $3.4 \%$ in August to $18.1 \%$ in November (mean 9.1\%). Finally, Stn C was dominated by nematodes that accounted for 83 to $98 \%$ of total meiofaunal density in January and June, respectively (mean 90\%). They were followed by copepods, ranging from 0.6 to $5.5 \%$, in June and November, respectively. Nauplii accounted for 0.3 to $3.7 \%$ (mean $1.8 \%$ ). Polychaetes accounted for 0.2 to $14.1 \%$ of total meiofaunal density in June and January, respectively (mean $4.5 \%$ ). Am-

Hard-bottom meiofauna

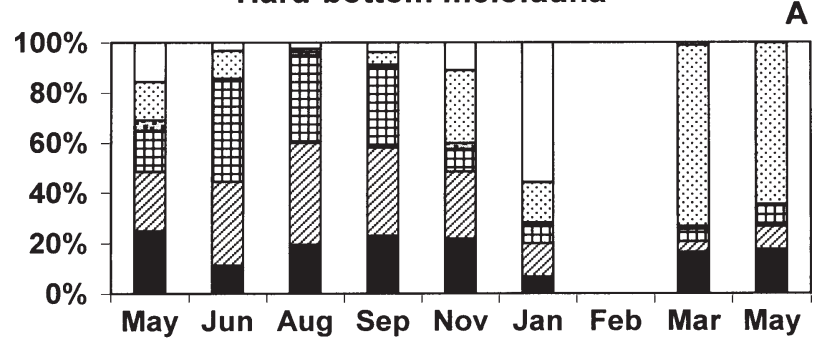

Hard-bottom meiofauna

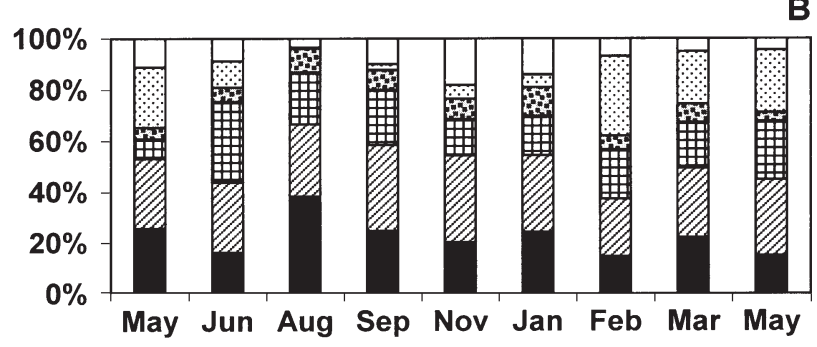

Soft-bottom meiofauna

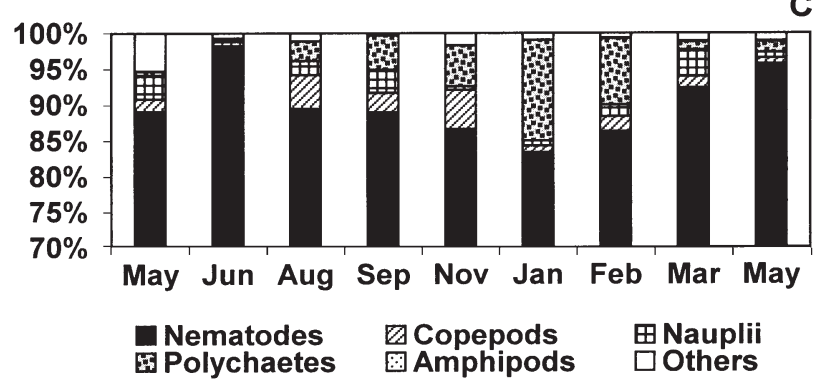

Fig. 6. Meiofaunal community structure at the 3 stations: (A) Stn A, (B) Stn B and (C) Stn C 


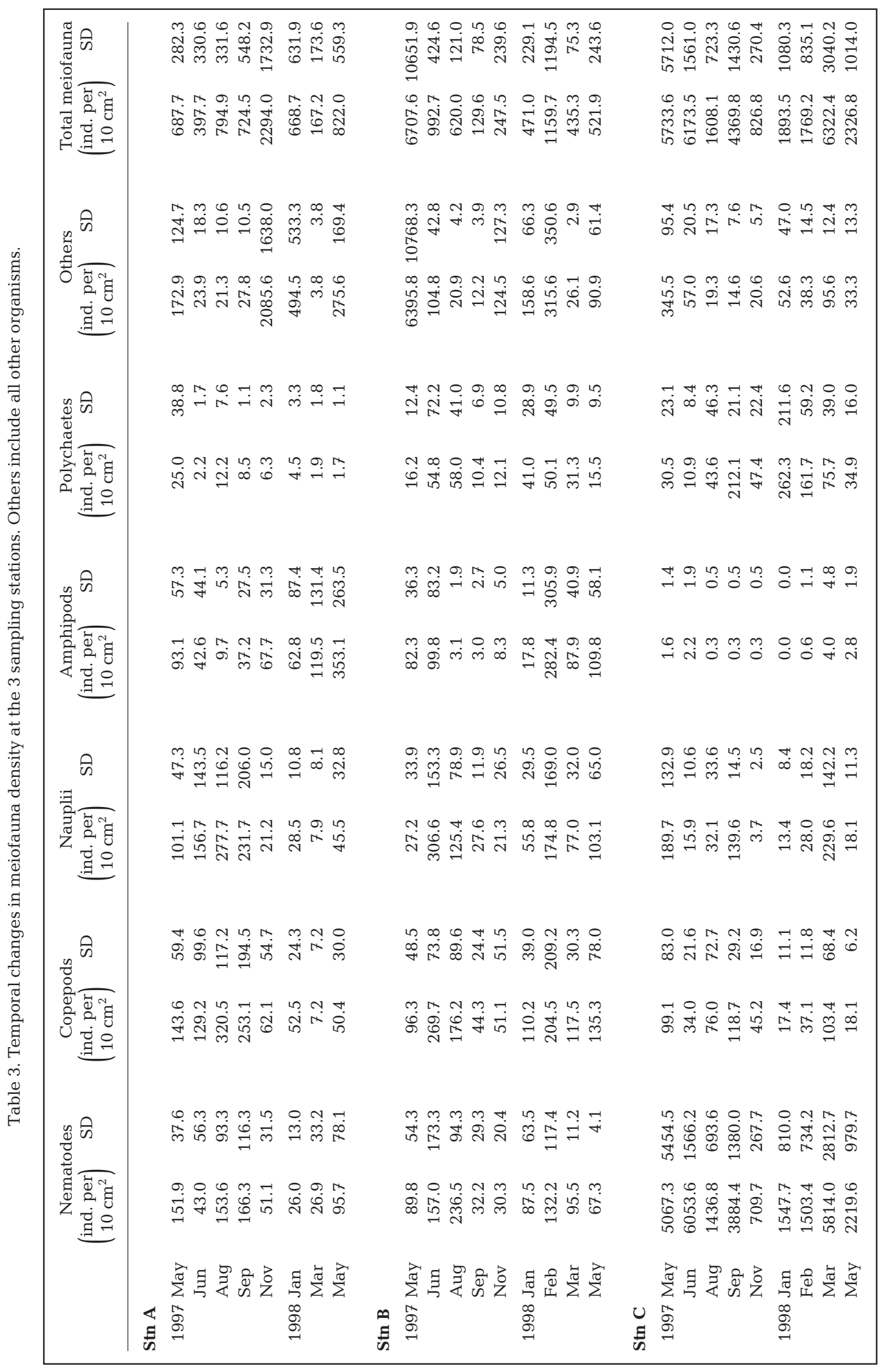


phipods accounted for a negligible meiofauna fraction. Other taxa accounted for 0.3 to $5.3 \%$ in September and May (mean 1.4\%.). Data from Stn A are lacking in February 1998 due to adverse meteorological conditions.

\section{Multivariate analyses}

The null hypothesis that assemblage structure was similar at all depths was rejected (2-way crossed ANOSIM, R = 0.649, $\mathrm{p}<0.001)$. The pair-wise tests showed that Stn A and Stn B were not significantly different (ANOSIM, R $=0.378, \mathrm{p}>0.5$; average dissimilarity between the 2 stations 19.80). Stn C significantly differed from both hard-substrate stations (ANOSIM, $\mathrm{R}=0.852, \mathrm{p}<0.001$ and $\mathrm{R}=0.778, \mathrm{p}<0.001$, respectively; average dissimilarity between Stns A and C was 33.43, and between Stns B and C was 28.54).
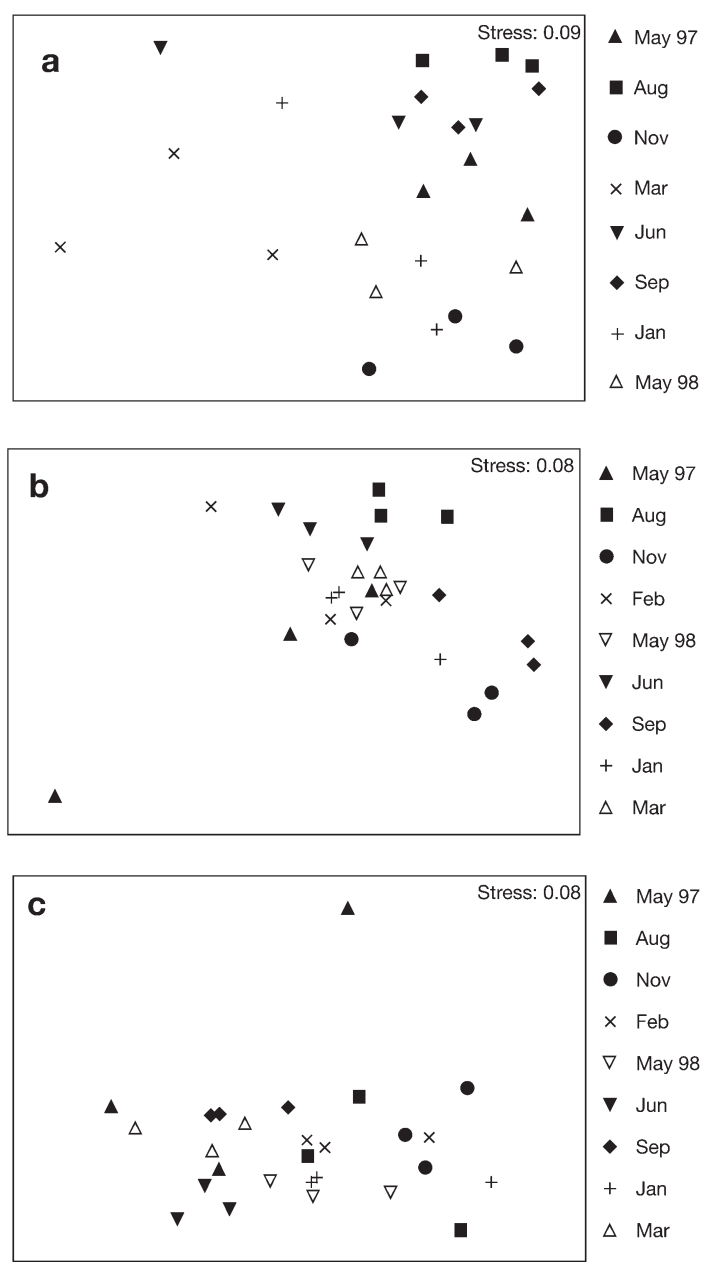

Fig. 7. Results of the MDS ordination of the 3 sampling stations: (a) Stn A, $2.5 \mathrm{~m}$ depth; (b) Stn B, $8 \mathrm{~m}$ depth and (c) Stn C, soft bottom. Reported are the 3 replicates at each sampling date
The results of the MDS ordination performed separately on the 3 stations are reported in Fig. 7a,b,c. They did not show any clear seasonality, besides the significant differences found with the 1-way ANOSIM analyses (ANOSIM: Stn A, R = 0.49, p < 0.001; Stn B, R = 0.337, $\mathrm{p}<0.001$; Stn $\mathrm{C}, \mathrm{R}=0.482$, $\mathrm{p}<0.001$ ). Replicate samples showed an annual average similarity value of $50.4 \pm 4.7 \%(\mathrm{SE})$ at Stn $\mathrm{A}, 62.7 \pm 5.7 \%$ at Stn B and $71 \pm 5.2 \%$ at the deepest station (Stn C).

Ordination of all replicates measured at all stations by MDS singled out 2 major groups: a major one comprising most of samples of Stns A and B, and one with all Stn C samples (stress value =0.09, Fig. 8).

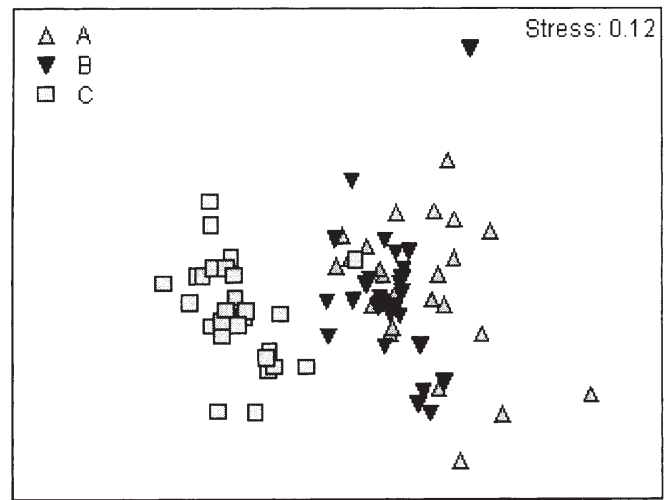

Fig. 8. Results of the MDS ordination pooling together the 3 sampling stations

SIMPER identified copepods as the taxon characterising both Stns A and B. Their contribution, expressed as a percentage, to the average similarity was $19.2 \%$ within Stn A, which displayed an average Bray-Curtis similarity of $78.7 \%$, within each group of samples. Copepods contributed to the average similarity of Stn B with 20.5\% and displayed an average Bray-Curtis similarity, within each group of samples, of $83.2 \%$. In contrast, Stn $\mathrm{C}$ was characterised by nematodes, which contributed $>40 \%$ to the average similarity $(82.4 \%)$ of this station. Nematodes were the group identified as responsible for the differences between hard- and soft-substrate stations.

\section{DISCUSSION}

\section{Hard- versus soft-substrate meiofaunal assemblages}

The 2 hard-substrate stations displayed very similar meiofaunal densities, which, as an annual average, were about 7 times lower than those in soft sediments at the base of the vertical cliff. There is a large body of information on soft-bottom meiofauna, and densities reported here at Stn $\mathrm{C}$ fall within the range of other 
studies carried out in the Adriatic Sea (Danovaro et al. 2000). On the other hand, little information is available for hard substrates and even less in terms of comparisons between hard- and soft-bottom meiofauna. So far, indeed, most studies have dealt with meiofauna associated with macroalgae (Healy 1996, Jarvis \& Seed 1996), without considering the association with the rock surface beneath the algae (Gibbons \& Griffiths 1988). In addition, most investigations were restricted to the intertidal zone (Gibbons 1988a,b, Williamson \& Creese 1996). Plant surface is commonly used as a means for comparison, but its use has been criticised (Gibbons 1988b), and most studies reported meiofaunal densities normalised to gram of epiphyte biomass. When our results are normalised to gram of algal biomass, values fall within the range of previous studies (Jarvis \& Seed 1996), but a significantly higher meiofaunal abundance was observed at Stn B (annual average, 588 ind. $\mathrm{g}^{-1}$ ) than at $\mathrm{Stn} \mathrm{A}$ (143 ind. $\mathrm{g}^{-1}$ ).

Previous studies on meiofaunal assemblages associated with macroalgae reported the dominance of copepods, while nematodes accounted for a minor fraction (Coull et al. 1983, Beckley \& McLachlan 1980). In our study, hard substrates were dominated by crustaceans (amphipods, copepods and nauplii), while nematodes accounted only for a minor fraction. As indicated by the ANOSIM analysis, no significant structural differences were observed comparing hard-substrate assemblages at the 2 depths, but clear differences were observed comparing hard- and soft-bottom meiofauna (Fig. 8). On hard substrates, according to previous findings dealing the vagile macrofaunal component (Giangrande 1988), meiofaunal polychaetes also increased their relevance with increasing depth (i.e. moving from Stn A to Stn B). Stn A, characterised by the presence of Mytilus galloprovincialis at its upper limit, was dominated by amphipods, followed by copepods and nauplii; at Stn B the importance of amphipods decreased and the copepod percentage increased. Conversely, soft-bottom meiofauna, as expected, was strongly dominated by nematodes (ca. $90 \%$ ), and here amphipods disappeared almost completely.

In this regard studies on meiofauna associated with the Rhodophyta Gelidium pristoides also reported crustaceans as the dominant fraction (Gibbons 1988b), and consistent with these results, we found that meiofaunal assemblages were dominated by amphipods and molluscs on wave-exposed substrates, and by copepods and nauplii on sheltered substrates. This result provides indication of the potential role of hydrodynamic stress on meiofaunal assemblage structure.

Previous studies reported the absence of significant temporal changes (Jarvis \& Seed 1996) and attributed the relative stability of meiofaunal assemblages to the unlimited nutritional resources offered by macroalgal coverage (Hicks 1989). Conversely, in the present study, meiofaunal density on hard and soft substrates displayed significant temporal changes. These results are consistent with those reported by Johnson \& Sheibling (1987), suggesting that seasonal changes in density are linked to epiphyte life cycles rather than to an intrinsic seasonality in animal populations. Meiofaunal assemblage, indeed, displayed significant temporal changes at all stations, but only at Stns A and B (hard substrates) did nematodes, copepods, polychaetes and amphipods display higher densities in spring to summer and lower densities in winter.

In November 1987, May 1998 (at Stn A), May 1997 and February 1998 (at Stn B), hard substrates were characterised by an important recruitment of Mytilus galloprovincialis (encountered in our samples as a temporary meiofauna, sensu Higgins \& Thiel 1988). $M$. galloprovincialis rapidly reached macrofaunal size at Stn A, but did not settle at Stn B, and the hydrodynamic conditions in the area did not allow the biodeposition of mussel excrements on soft sediments beneath the cliff. In August, mucilage aggregates covered the cliff and largely impacted mussel populations (see Table 1), but neither the massive recruitment of this bivalve nor the mucilage disturbance affected meiofaunal assemblages. These results strongly suggest that different factors affected sessile macrofauna and meiofauna inhabiting hard substrates.

\section{Factors controlling hard-bottom meiofauna}

The results of our study indicate that the primary factors affecting meiofaunal density are the nature and structure of the primary substrate. This is evident also from MDS analysis, which pooled together all hard substrate samples and discriminated soft-bottom samples (Fig. 8). Hard substrates lack interstitial space, so meiofauna have a reduced possibility of colonisation. Despite the reduced meiofaunal density, values we encountered on hard substrates were comparable to values reported from several subtidal soft-bottom environments (Higgins \& Thiel 1988 and citations therein). The structure of the primary substrate is limiting, but not halting to meiofaunal colonisation, which profited from the substrate heterogeneity created by epibiontic organisms. Nematodes, indeed, were related to the SCI ( $\mathrm{p}$ 0.05), which, in turn, is related to the capability of the system to trap sediments and create microniches essential for nematode colonisation. With the exception of August when mucilage covered the cliff, copepod and nauplius densities were related to the TSC ( $p<0.05)$. In August, copepods and nauplii reached highest densities possibly due to their ability 
to utilise mucilage as a trophic source (Shanks \& Walters 1997). Only amphipods were significantly correlated with algal biomass $(\mathrm{R}=0.805, \mathrm{p}<0.01)$. In this regard it has been previously demonstrated that amphipods possess a biological cycle closely related to macrophytes, which offer nutrition and refuge from predation (Beckley 1980). The lack of any correlation of copepods and nauplius density with algal coverage and biomass could suggest that these taxa find alternative structures as refuges from resuspension and/or from predation. Stn A is, indeed, also largely covered by a mussel bed, and wave action defers sedimentation in the spaces between bivalves. In contrast, at Stn B (8 $\mathrm{m}$ depth), the mussel belt is absent, wave energy is reduced and the amount of sediment deposited increased. Here, despite the limited algal development, the most important taxa (i.e. copepods and their nauplii and amphipods) were significantly correlated with algal coverage $(R=0.771,0.867$ and 0.742 , respectively, all $\mathrm{p}<0.01$ ), but not with TSC or SCI. This could suggest that at Stn B algae might serve as a food source rather than as a refuge from predation or protection from resuspension; moreover, this apparently indicates a reduced hydrodynamic impact in the deeper hard-bottom station.

Besides the primary role of substrate structure and complexity, our results suggest that different variables might influence hard-substrate meiofauna at the 2 investigated depths. At Stn A, the hydrodynamic stress certainly played an important role in meiofaunal abundance, structure and dynamics. Meiofaunal abundance was positively correlated with transparency $(\mathrm{n}=8$, $\mathrm{R}=0.821$ and $0.767, \mathrm{p}<0.01)$ and negatively with sea conditions ( $\mathrm{n}=8, \mathrm{R}=0.679, \mathrm{p}<0.05)$, indicating that meiofaunal and/or sediment resuspension and deposition might represent important processes influencing meiofaunal colonisation and/or permanence over hard substrata. This was also confirmed by the analysis of similarities among replicates within each station, which revealed a decreasing spatial variability of meiofaunal assemblages with increasing depth. Caswell \& Cohen (1991) first hypothesised that disturbance might induce higher spatial variability in communities. Warwick \& Clarke (1993) and Fraschetti et al. (2001) consistently recorded increased variability among replicate samples from several different benthic communities exposed to increasing disturbance levels, thus supporting this hypothesis (but see also Chapman et al. 1995 for different findings). The results of our study suggest that this may represent a general rule, but also confirmed that hydrodynamic stress played an important role in meiofaunal structure and distribution on hard substrates, especially at shallow depths. Moreover, despite hard substrate meiofaunal density (normalised to $10 \mathrm{~cm}^{2}$ ) being identical at the 2 depths, 3-fold higher values were encountered at Stn B, but normalising meiofaunal abundance to algal biomass. This indicates that hydrodynamic stress can also be an important factor affecting the ability of meiofauna to colonise the secondary substrate, but is not sufficient, at least in our study, to determine significant differences between the 2 hard-substrate assemblages.

Acknowledgements. This work was carried out within the frame work of the project Biodiversity $(60 \%)$ of the University of Bari, and partially supported by MURST. The authors would like to thank Luca Casadio for valuable contribution to sampling and meiofaunal sorting, and Tiziana Romagnoli for kindly helping in taxonomic identification of algal assemblages. Thanks are also due to Cristina Gambi and Fabio Massimo Perrone for suggestions on an earlier draft of the manuscript.

\section{LITERATURE CITED}

Airoldi L (1998) Roles of disturbance, sediment stress, and substratum retention on spatial dominance in algal turf. Ecology 79:275-277

Albertelli G, Covazzi-Harriague A, Danovaro R, Fabiano M, Fraschetti S, Pusceddu A (1999) Differential responses of bacteria meiofauna and macrofauna in a shelf area (Ligurian Sea, NW Mediterranean): role of food availability. J Sea Res 42:11-26

Aller RC, Aller JY (1992) Meiofauna and solute transport in marine muds. Limnol Oceanogr 37:1018-1033

Artegiani A, Azzolini R (1981) Influence of the Po floods on the western Adriatic coastal water up to Ancona and beyond. Rapp P-V Reun Comm Int Explor Sci Mer Mediterr 27:115-119

Beckley LE (1980) Distribution and tidal rhythmicity of a littoral amphipod. Tydskr S-Afr Dierkd 15:199-200

Beckley LE (1982) Studies on the littoral seaweed epifauna of St. Croix Island. III. Gelidium pristoides (Rhodophyta) and its epifauna. S Afr J Zool 17:3-10

Beckley LE, McLachlan A (1979) Studies on the littoral seaweed epifauna of St. Croix Island. I. Physical and biological features of the littoral zone. S Afr J Zool 14:175-182

Beckley LE, McLachlan A (1980) Studies on the littoral seaweed epifauna of St. Croix Island. II. Composition and summer standing stock. S Afr J Zool 15:170-176

Boucher G, Gorbault N (1990) Sublittoral meiofauna and diversity of nematode assemblages off Guadeloupe Islands (French West Indies). Bull Mar Sci 47:448-463

Caswell H, Cohen JE (1991) Communities in patchy environments: a model of disturbance, competition, and heterogeneity. In: Kolasa J, Pickett STA (eds) Ecological heterogeneity. Springer-Verlag, New York, p 97-122

Chapman MG, Underwood AJ, Skilleter GA (1995) Variability at different spatial scales between a subtidal assemblage exposed to the discharge of sewage and two control assemblages. J Exp Mar Biol Ecol 189:103-122

Clarke KR (1993) Non-parametric multivariate analyses of changes in community structure. Aust J Ecol 18:117-143

Clarke KR, Warwick RM (1994) Change in marine communities: an approach to statistical analysis and interpretation. Natural Environment Research Council, Plymouth

Clarke KR, Warwick RM (1999) The taxonomic distinctness measure of biodiversity: weighting of step lengths between hierachical levels. Mar Ecol Prog Ser 184:21-29

Coull BC (1999) Role of meiofauna in estuarine soft-bottom 
habitats. Aust J Ecol 24:327-343

Coull BC, Wells JBJ (1982) Refuges from fish predation: experiments with phytal meiofauna from the New Zealand rocky intertidal. Ecology 64:1599-1609

Coull BC, Creed EL, Eskin RA, Montagna PA, Palmer MA, Wells JBJ (1983) Phytal meiofauna from the rocky intertidal at Murrells Inlet, South Carolina. Trans Am Microsc Soc 102:380-389

Crowe WA, Joseison AB, Svane I (1987) Influence of adult density on recruitment into soft sediments: a short-term in situ sublittoral experiment. Mar Ecol Prog Ser 41:61-69

Danovaro R, Fabiano M, Albertelli G, Della Croce N (1995) Vertical distribution of meiobenthos in bathyal sediments of the eastern Mediterranean Sea: relationship with labile organic matter and bacterial biomasses. PSZN I: Mar Ecol 16:103-116

Danovaro R, Gambi C, Manini E, Fabiano M (2000) Meiofauna response to a dynamic river plume front. Mar Biol 137:359-370

Fleeger JW, Shirley TC, McCall JN (1995) Fine-scale vertical profiles of meiofauna in muddy subtidal sediments. Can J Zool 73:1453-1460

Fraschetti S, Bianchi CN, Terlizzi A, Fanelli G, Morri C, Boero F (2001) Spatial variability and human disturbance in shallow subtidal hard bottom assemblages: a regional approach. Mar Ecol Prog Ser 212:1-12

Gee JM, Warwick RM (1994) Metazoan community structure in relation to the fractal dimensions of marine macroalgae. Mar Ecol Prog Ser 103:141-150

Giangrande A (1988) Polychaete zonation and its relation to algal distribution down a vertical cliff in the western Mediterranean (Italy): a structural analysis. J Exp Mar Biol Ecol 120:263-276

Gibbons MJ (1988a) The impact of sediment accumulations, relative habitat complexity and elevation on rocky shore meiofauna. J Exp Mar Biol Ecol 122:225-241

Gibbons MJ (1988b) The impact of wave exposure on the meiofauna of Gelidium pristoides (Turner) Kuetzing (Gelidiales: Rhodophyta). Estuar Coast Shelf Sci 27:581-593

Gibbons MJ, Griffiths CL (1988) An improved method for estimating meiofaunal standing stock on an exposed rocky shore. S Afr J Mar Sci 6:55-58

Hall MO, Bell SS (1988) Response of small motile epifauna to complexity of epiphytic alga on seagrass blades. J Mar Res 46:613-630

Healy B (1996) The distribution of Oligochaeta on an exposed

Editorial responsibility: Otto Kinne (Editor),

Oldendorf/Luhe, Germany rocky shore in southeast Ireland. Hydrobiologia 334:51-62

Hicks GRF (1980) Structure of phytal harparcticoid copepod assemblages and the influence of habitat complexity and turbidity. J Exp Mar Biol Ecol 44:147-192

Hicks GRF (1989) Does epibenthic structure negatively affect meiofauna? J Exp Mar Biol Ecol 133:39-55

Higgins RP, Thiel H (1988) Introduction to the study of meiofauna. Smithsonian Institution Press, London

Jarvis SC, Seed R (1996) The meiofauna of Ascophyllum nodosum (L.) Le Joilis: characterization of assemblages associated with two common epiphytes. J Exp Mar Biol Ecol 199:249-267

Johnson SC, Sheibling RE (1987) Structure and dynamics of epifaunal assemblages of macroalgae Ascophyllum nodosum and Fucus vesciculosus in Nova Scotia, Canada. PSZN I: Mar Ecol 37:209-227

Ólafsson E (1995) Meiobenthos in mangrove areas in eastern Africa with emphasis on assemblage structure of freeliving marine nematodes. Hydrobiologia 312:47-57

Russo AR (1990) The role of seaweed complexity in structuring Hawaiian epiphytal amphipod communities. Hydrobiologia 94:1-12

Shanks AL, Walters K (1997) Holoplankton, meroplankton and meiofauna associated with marine snow. Mar Ecol Prog Ser 156:75-86

Steyaert M, Garner N, van Gansbeke D, Vincx M (1999) Nematode communities from the North Sea: environmental controls on species diversity and vertical distribution within the sediment. J Mar Biol Assoc UK 79:253-264

Stoner AW, Lewis FG III (1985) The influence of quantitative and qualitative aspects of habitat complexity in tropical seagrass meadows. J Exp Mar Biol Ecol 94:19-40

Sutherland JP, Ortega S (1986) Competition conditional on recruitment and temporary escape from predators on a tropical rocky shore. J Exp Mar Biol Ecol 95:155-166

Vanhove S, Lee HJ, Beghyn M, VanGansbeke D, Brockington S, Vincx M (1998) The metazoan meiofauna in its biogeochemical environment: the case of an Antarctic coastal sediment. J Mar Biol Assoc UK 78:411-434

Warwick RM, Clarke KR (1993) Increased variability as a symptom of stress in marine communities. J Exp Mar Biol Ecol 172:215-226

Williamson JE, Creese RG (1996) Small invertebrates inhabiting the crustose alga Pseudolithoderma sp. (Relfsiacae) in northern New Zealand. NZ J Mar Freshw Res 30: 221-232

Submitted: April 6, 2001; Accepted: August 21, 2001

Proofs received from author(s): March 11, 2002 